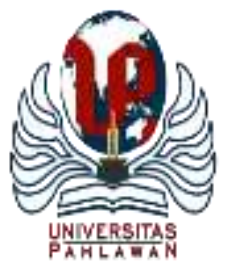

Edukatif : Jurnal Ilmu Pendidikan Volume 4 Nomor 1 Tahun 2022 Halm 1219 - 1228

EDUKATIF: JURNAL ILMU PENDIDIKAN

Research \& Learning in Education

https://edukatif.org/index.php/edukatif/index

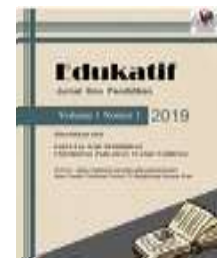

\title{
Pengembangan Buku Digital Muatan Pelajaran IPS berbasis Mobile Learning pada Materi Kerajaan-Kerajaan Hindu, Buddha, dan Islam di Indonesia
}

\author{
Juliandari Nur Fajri ${ }^{1 凶}$, Edwita ${ }^{2}$, Yustia Suntari ${ }^{3}$ \\ Universitas Negeri Jakarta, Indonesia ${ }^{1,2,3}$ \\ E-mail : juliandarinur@gmail.com ${ }^{1}$, edwita@unj.ac.id ${ }^{2}$, yustiasuntari@unj.ac.id ${ }^{3}$
}

\begin{abstract}
Abstrak
Penelitian dan pengembangan ini bertujuan guna menghasilkan produk berupa buku digital muatan pelajaran IPS berbasis mobile learning pada materi kerajaan-kerajaan Hindu, Buddha, dan Islam di Indonesia kelas IV SD. Penelitian dan pengembangan buku digital mengacu pada metode research and development dengan mengadopsi model pengembangan ADDIE atas 5 tahapan, yaitu analyze, design, development, implementation, dan evaluation. Responden penelitian ini mencakup ahli materi, ahli media, ahli bahasa, guru kelas IV sekolah dasar, dan 38 peserta didik kelas IV SD. Teknik pengumpulan data yang digunakan adalah wawancara dan kuesioner dengan metode analisis data menggunakan statistik deskriptif. Hasil penelitian dan pengembangan menunjukkan tingkat kelayakan buku digital muatan pelajaran IPS berbasis mobile learning memperoleh persentase sebesar $90 \%$ untuk uji ahli materi, $100 \%$ untuk uji ahli media, dan $100 \%$ untuk uji ahli bahasa. Selanjutnya untuk uji coba peserta didik tahap one to one, small group, dan field test, masing-masing tahap memperoleh persentase tingkat kelayakan sebesar $90,8 \%, 94,5 \%$, dan 90,91\%. Berdasarkan hasil penelitian dan pengembangan tersebut, maka buku digital muatan pelajaran IPS berbasis mobile learning dinilai sangat layak, sehingga peserta didik dapat memanfaatkan buku digital dalam pembelajaran IPS pada materi kerajaan-kerajaan Hindu, Buddha, dan Islam di Indonesia kelas IV SD. Kata Kunci: Penelitian dan Pengembangan, Buku Digital, Mobile Learning, Ilmu Pengetahuan Sosial, KerajaanKerajaan Hindu, Buddha, dan Islam di Indonesia.
\end{abstract}

\begin{abstract}
This research and development $(R \& D)$ study aims to create a digital book for social sciences subject based on mobile learning on the material of Hindu, Buddhist, and Islamic kingdoms in Indonesia for the fourth grade of elementary school. It refers to the R\&D method by adopting the ADDIE development model which consists of 5 stages, i.e., analyze, design, development, implementation, and evaluation. Respondents are material and media experts, linguists, fourth-grade elementary school teachers, and 38 students. Interviews and questionnaires are used to collect the data. The descriptive statistics method is used to analyze the statistical data. The results show that the feasibility level of social sciences subject digital books with mobile learning-based is $90 \%$ for the material expert test, $100 \%$ for the media expert test, and 100\% for the linguist test. Furthermore, at the one-to-one stage student trial, small group stage trial, and field test stage, it obtained 90.8\%, 94,5\%, and 90,91\% of the feasibility level on each stage. Based on the results, the digital book for social sciences subject with mobile learning-based is considered very feasible, so the fourth-grade elementary school students can use digital books in social sciences on Hindu, Buddhist, and Islamic kingdoms in Indonesia.
\end{abstract}

Keywords: Research \& Development Study, Digital Book, Mobile Learning, Social Sciences, Hindu, Buddhist, and Islamic Kingdoms in Indonesia.

Copyright (c) 2022 Juliandari Nur Fajri, Edwita, Yustia Suntari

$\triangle$ Corresponding author:

Email : juliandarinur@gmail.com

DOI : https://doi.org/10.31004/edukatif.v4i1.1918

ISSN 2656-8063 (Media Cetak) ISSN 2656-8071 (Media Online)

Edukatif : Jurnal Ilmu Pendidikan Vol 4 No 1 Tahun 2022 p-ISSN 2656-8063 e-ISSN 2656-8071 
1220 Pengembangan Buku Digital Muatan Pelajaran IPS berbasis Mobile Learning pada Materi KerajaanKerajaan Hindu, Buddha, dan Islam di Indonesia - Juliandari Nur Fajri, Edwita, Yustia Suntari DOI: https://doi.org/10.31004/edukatif.v4i1.1918

\section{PENDAHULUAN}

Ilmu Pengetahuan Sosial (IPS) adalah salah satu muatan pelajaran yang telah dipelajari oleh peserta didik sejak jenjang Sekolah Dasar (SD). IPS didefinisikan sebagai penggabungan dari berbagai cabang ilmu sosial seperti sejarah, ekonomi, geografi, politik, hukum, dan budaya yang disusun secara interdisipliner dan kemudian disesuaikan kembali dengan kepentingan dan kebutuhan pendidikan dan pembelajaran di sekolah (Karim, 2015). Melalui pembelajaran IPS di sekolah, peserta didik diharapkan mampu untuk menanamkan konsep-konsep sosial agar dapat terbentuk sikap dan kepribadian yang baik di masyarakat. Pembelajaran konsep IPS bermakna yang ditanamkan di sekolah diharapkan dapat menumbuhkan rasa kesadaran dalam diri tiap peserta didik karena pada dasarnya mereka ialah makhluk sosial yang hidup di tengah masyarakat (Inah, 2013). Pemahaman konsep-konsep IPS yang bermakna tentu saja berkaitan dengan kondisi kehidupan sosial yang terjadi di tengah masyarakat, sehingga peserta didik dapat mengaplikasikannya ketika akan berkontribusi di masyarakat. Oleh sebab itu, dalam kegiatan belajar mengajar di sekolah, khususnya pada pembelajaran IPS, seorang guru memiliki tanggung jawab untuk memilih bahan ajar sebagai sumber belajar yang tepat untuk digunakan agar pembelajaran dan penanaman konsep tepat sasaran. Hal ini ditujukan agar setiap peserta didik memiliki dorongan dan keinginan dari dalam dirinya untuk belajar dengan sumber yang disediakan oleh guru.

Pada umumnya, bahan ajar yang digunakan oleh guru dan peserta didik dapat berupa buku tematik, modul, dan Lembar Kerja Peserta Didik (LKPD). Dalam usaha mencegah terjadinya kekurangan referensi materi, guru dianjurkan untuk tidak hanya memanfaatkan satu jenis bahan ajar saja agar setiap bahan ajar dapat melengkapi satu sama lain. Sebuah kegiatan pembelajaran juga dapat dioptimalkan dengan penggunakan buku pengayaan atau buku suplemen yang dapat menambah pengetahuan peserta didik. Pada dasarnya, buku pengayaan atau buku suplemen termasuk ke dalam kategori buku non teks pelajaran. Menurut Permendikbud Nomor 81 Tahun 206 tentang Buku Yang Digunakan Oleh Satuan Pendidikan, buku non teks pelajaran adalah buku pengayaan untuk mendukung proses pembelajaran pada setiap jenjang dan jenis buku lain yang tersedia di perpustakaan sekolah (Permendikbud, 2016). Hal ini sejalan dengan buku suplemen yang didefinisikan sebagai sumber belajar yang dimanfaatkan guna menunjang pemahaman peserta didik mengenai materi dari sebuah mata pelajaran (Abdillah, Degeng, \& Husna, 2020). Buku suplemen pada dasarnya mengacu dari buku teks pelajaran yang memiliki beberapa fungsi sebagai berikut: 1) Sarana pengembangan bahan dan program dalam kurikulum pendidikan; 2) Sarana pelancar tugas akademik guru; 3) Sarana pelancar ketercapaian guru; 3) Sarana pelancar ketercapaikan tujuan pembelajaran; dan 4) Sarana pelancar efisiensi dan efektivitas kegiatan pembelajaran (Masnur Muslich, 2010). Melalui pemanfaatan buku suplemen, peserta didik diharapkan dapat memperkaya wawasannya secara mandiri dan tidak terbatas ruang dan waktu demi tercapainya tujuan pembelajaran.

Pada Era Revolusi Industri 4.0 saat ini, seluruh aspek di dunia mengalami perubahan, tidak terkecuali pada bidang pendidikan. Pendidikan di Era Revolusi Digital menuntut adanya pemanfaatan teknologi digital sebagai alat bantu peningkatan mutu akademik (Cholily, Putri, \& Kusgiarohmah, 2019). Perkembangan teknologi digital yang sangat pesat menyebabkan penggunaan teknologi manual semakin tergeser karena masyarakat cenderung beralih ke teknologi digital. Contohnya, penggunaan komputer dalam pembelajaran dewasa ini tergeser dengan adanya laptop yang lebih fleksibel. Pemanfaatan teknologi dalam bidang pendidikan yang paling menonjol adalah minimalisasi penggunaan kertas (paperless). Paperless diartikan sebagai sebuah upaya pembaharuan yang dilakukan dalam kegiatan konservasi di dunia pendidikan dengan mengurangi penggunaan kertas dan mulai beralih ke penggunaan buku digital atau electronic book (e-book) (Purwo et al., 2021).

Pembaharuan pemanfaatan teknologi informasi dan komunikasi dalam bidang pendidikan tidak hanya berputar pada penggunaan laptop dan paperless saja, melainkan juga timbulnya pembaharuan pada proses pembelajaran. Penggunaan teknologi informasi dan komunikasi di bidang pendidikan senantiasa berkembang 
1221 Pengembangan Buku Digital Muatan Pelajaran IPS berbasis Mobile Learning pada Materi KerajaanKerajaan Hindu, Buddha, dan Islam di Indonesia - Juliandari Nur Fajri, Edwita, Yustia Suntari DOI: https://doi.org/10.31004/edukatif.v4i1.1918

dalam bermacam-macam metode. Salah satunya adalah berkembangnya sistem pembelajaran e-learning (electronic learning). Istilah e-learning berasal dari dua kata, yaitu: $E$ dan learning. E merupakan singkatan dari electronic yang berarti benda yang diciptakan dibuat mengacu pada prinsip elektronika. Sedangkan learning diartikan sebagai belajar atau pembelajaran. Maka dapat didefinisikan bahwa e-learning merupakan proses belajar atau pembelajaran yang dapat diakses melalui pemanfaatan perangkat elektronik seperti komputer (Simanihuruk et al., 2019). Seiring berkembangnya teknologi informasi dan komunikasi, hal ini menyebabkan e-learning mengalami terobosan-terobosan baru. Salah satunya adalah dengan lahirnya inovasi baru berupa mobile learning. Mobile learning didefinisikan sebagai cabang dari e-learning yang memanfaatkan perangkat seluler untuk mengakses pembelajaran (Samsinar, 2020). Inovasi tersebut memberikan kebebasan kepada peserta didik untuk mengakses materi pembelajaran tidak terikat ruang dan waktu.

Pada masa pandemi COVID-19 yang saat ini tengah melanda dunia, seluruh tatanan kehidupan juga mengalami perubahan. Dalam ranah pendidikan, seluruh kegiatan belajar mengajar di sekolah dialihkan menjadi pembelajaran jarak jauh. Proses pembelajaran jarak jauh menuntut guru untuk menyusun pembelajaran mobile learning sebagai alternatif pengganti pembelajaran tatap muka, sehingga peserta didik dapat mengakses materi pembelajaran secara fleksibel.

Peneliti memperoleh hasil analisis kebutuhan terhadap guru kelas IV SDN Utan Kayu Selatan 05 melalui wawancara pada Senin, 30 November 2020. Berdasarkan hasil wawancara tersebut, diperoleh hasil bahwa pembelajaran IPS kelas IV khususnya pada materi sejarah kerajaan-kerajaan Hindu, Buddha, dan Islam di Indonesia terbilang lancar. Tetapi, pada masa pandemi COVID-19 ini masih terdapat kendala dari peserta didik yang kurang fokus dan kurang semangat dalam membaca buku tematiknya. Salah satu penyebabnya adalah materi yang tersaji dalam buku tematik masih kurang lengkap dan kurang menarik perhatian peserta didik, sehingga buku tematik tersebut belum mampu memacu rasa keingintahuan mereka. Hal ini tentu saja menjadi kendala yang kerap dirasakan oleh guru. Saat pembelajaran di kelas, guru hanya menggunakan dua buku pegangan sebagai bahan ajar, yaitu buku tematik untuk guru dari Kementerian dan Kebudayaan dan buku penilaian autentik (Bupena). Namun, pada Bupena tersebut lebih difokuskan pada contoh soal dibandingkan dengan isi materinya, sedangkan peserta didik hanya memakai buku tematik untuk peserta didik dari Kementerian Pendidikan dan Kebudayaan sebagai buku pegangan utama. Akibat dari permasalahan yang kerap terjadi, guru harus menyiasatinya dengan mencari referensi lain dari berbagai sumber. Apabila peserta didik dianggap memerlukan referensi tambahan, guru akan menampilkan tayangan video yang berisi materi yang dipelajari. Selain itu, guru menilai bahwa buku tematik dan buku Bupena masih kurang menunjang untuk pembelajaran IPS, khususnya pada materi kerajaan Hindu, Buddha, dan Islam di Indonesia.

Oleh karena itu, diperlukan sumber belajar penunjang berupa buku suplemen yang dapat dimanfaatkan peserta didik selama pembelajaran mengenai kerajaan-kerajaan Hindu, Buddha, dan Islam di Indonesia. Buku suplemen yang diperlukan pun disesuaikan pada perkembangan zaman karena anak-anak cenderung lebih tertarik untuk memainkan gawai pintar (gadget) daripada membaca buku fisik secara langsung. Dengan demikian, peserta didik memerlukan sumber belajar yang lengkap dan dapat menunjang kebutuhan peserta didik dan bersifat fleksibel sehingga mudah untuk diakses dari gadget mereka masing-masing di manapun dan kapanpun.

Selanjutnya, berdasarkan wawancara dengan peserta didik, diperoleh informasi bahwa selama pandemi COVID-19, mereka terkadang merasa kesulitan dalam mengerjakan tugas dan memahami materi pembelajaran IPS, khususnya pada materi kerajaan-kerajaan Hindu, Buddha, dan Islam di Indonesia. Hal ini dikarenakan peserta didik harus tetap mengakses mesin pencari (Google.com) untuk mencari materi yang digunakan untuk mengerjakan tugas karena peserta didik merasa kesulitan dalam mencari jawaban di dalam buku tematik. Melihat kenyataan tersebut, peserta didik merasa membutuhkan pembelajaran IPS yang jauh 
1222 Pengembangan Buku Digital Muatan Pelajaran IPS berbasis Mobile Learning pada Materi KerajaanKerajaan Hindu, Buddha, dan Islam di Indonesia - Juliandari Nur Fajri, Edwita, Yustia Suntari

DOI: https://doi.org/10.31004/edukatif.v4i1.1918

lebih mudah dan menarik untuk digunakan dan tidak perlu mengakses mesin pencari sehingga dapat dilakukan secara mandiri dan tidak perlu bantuan orang dewasa.

Oleh karena itu, berdasarkan hasil wawancara dengan guru dan peserta didik ditemukan adanya kebutuhan akan penggunaan bahan ajar atau sumber belajar berupa buku suplemen dalam bentuk digital bagi peserta didik. Seiring berjalannya waktu, perkembangan teknologi di dunia pendidikan yang semakin berkembang, dewasa ini banyak bermunculan penelitian mengenai pengembangan buku suplemen dalam bentuk digital untuk peserta didik sekolah dasar.

Salah satu penelitian pengembangan mengenai buku suplemen digital menyimpulkan bahwa media digital book berbasis FLIP Pdf Professional efektif untuk meningkatkan keaktifan peserta didik dalam pembelajaran (Febrianti, 2021). Terdapat pula penelitian lain yang membahas pengembangan digibook menampilkan hasil bahwa pengembangan buku digital (digibook) sangat sesuai dengan kebutuhan anak pada tingkat SD dan penggunaannya cukup efektif dalam membantu peserta didik memahami materi pembelajaran serta dapat meningkatkan hasil belajar (Marselina \& Muhtadi, 2019; Yayuk, 2017).

Berdasarkan hal-hal yang telah dijabarkan di atas, maka peneliti tertarik untuk melakukan penelitian pengembangan guna mengembangkan sebuah bahan ajar yaitu buku suplemen berbentuk digital berbasis mobile learning dengan judul "Pengembangan Buku Digital Muatan Pelajaran IPS Berbasis Mobile Learning Pada Materi Kerajaan-Kerajaan Hindu, Buddha, dan Islam di Indonesia". Penelitian pengembangan ini ditujukan agar peserta didik memiliki sumber belajar penunjang yang menarik dan dapat memperkaya wawasan dan ilmu pengetahuan, khususnya pada pembelajaran IPS materi kerajaan-kerajaan Hindu, Buddha, dan Islam di Indonesia.

\section{METODE PENELITIAN}

Penelitian ini bertujuan untuk menghasilkan produk berupa buku digital muatan IPS dengan materi Kerajaan-Kerajaan Hindu, Buddha, dan Islam di Indonesia. Metode yang digunakan dalam penelitian ini adalah metode penelitian pengembangan atau Research and Development (R\&D) dan mengadopsi langkahlangkah penelitian pengembangan pada model pengembangan ADDIE. Pengembangan buku digital tersebut dilakukan Oktober 2020-Agustus 2021.

Model pengembangan ADDIE merupakan salah satu model yang lazim digunakan dalam bidang pendidikan sebagai model yang dapat mewadahi para peneliti untuk mengembangkan produk berupa sumber belajar yang bersifat inovatif, otentik, dan inspiratif (Branch, 2009). Model pengembangan ADDIE merupakan siklus yang terdiri atas lima tahap proses, yaitu Analyze (analisis), Design (desain), Development (pengembangan), Implementation (implementasi), dan Evaluation (evaluasi) (Saputro, 2017).

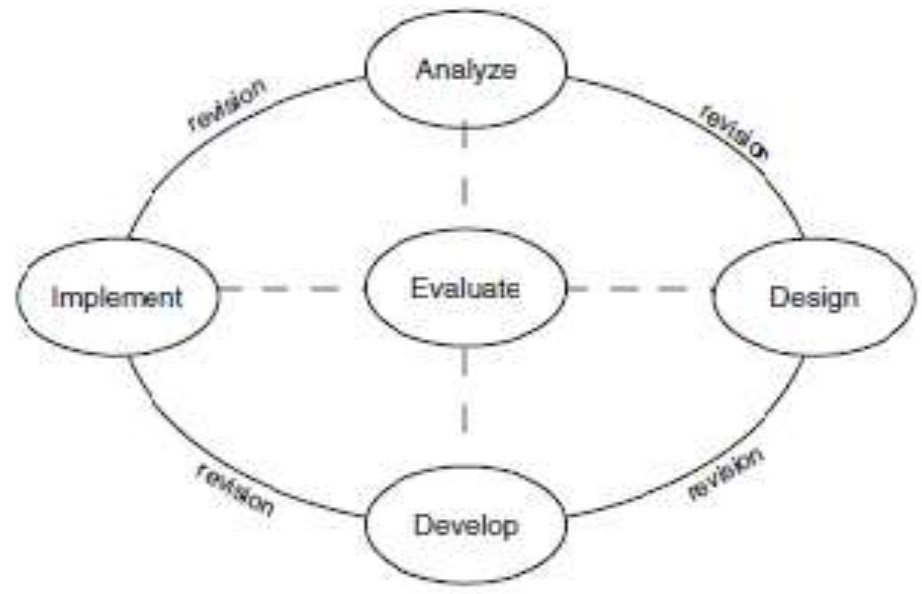

Gambar 1. Tahapan Model Pengembangan ADDIE

(Sumber: Branch, 2009) 
1223 Pengembangan Buku Digital Muatan Pelajaran IPS berbasis Mobile Learning pada Materi KerajaanKerajaan Hindu, Buddha, dan Islam di Indonesia - Juliandari Nur Fajri, Edwita, Yustia Suntari

DOI: https://doi.org/10.31004/edukatif.v4i1.1918

Responden dalam penelitian ini terdiri atas seorang ahli materi, seorang ahli media, dan seorang ahli bahasa. Peneliti juga melibatkan seorang guru dan 38 peserta didik kelas IV SDN Utan Kayu Selatan 05 sebagai responden.

Instrumen pengumpulan data berupa wawancara dan kuesioner. Wawancara merupakan teknik pengumpulan data yang digunakan apabila peneliti ingin melakukan studi pendahuluan untuk menemukan permasalahan yang harus diteliti, dan juga apabila peneliti ingin mengetahui hal-hal dari responden yang lebih mendalam dan jumlah respondennya sedikit atau kecil (Danuri \& Maisaroh, 2019). Kuesioner atau angket merupakan teknik pengumpulan data melalui sejumlah pertanyaan tertulis untuk mendapatkan informasi atau data dari sumber data atau responden (Syahrum \& Salim, 2014). Kuesioner atau angket yang disusun mengadopsi penggunaan skala likert. Skala likert merupakan skala yang umumnya digunakan seorang peneliti untuk mengukur sikap, pendapat, dan persepsi seseorang atau sekelompok orang tentang sebuah fenomena atau keadaan (Sugiyono, 2013). Skala likert yang digunakan dalam penelitian ini adalah skala likert dengan empat poin (four-point likert scale). Skala likert dengan empat poin memiliki keuntungan, yaitu menghilangkan adanya kemungkinan responden akan menyalahgunakan titik tengah atau pilihan netral (Chyung, Roberts, Swanson, \& Hankinson, 2017). Dalam skala likert, digunakan rentang skor 1-4 yang mendeskripsikan penilaian dari sangat kurang baik hingga sangat baik. Kategori penilaian skor dapat dilihat melalui Tabel 1 berikut ini.

Tabel 1

Skor Penilaian Terhadap Jawaban

\begin{tabular}{lc}
\hline Analisis Kuantitatif & Skor \\
\hline Sangat Kurang Baik & 1 \\
Kurang Baik & 2 \\
Baik & 3 \\
Sangat Baik & 4 \\
\hline
\end{tabular}

Data yang telah dikumpulkan melalui skor penilaian dari angket kemudian dianalisis dengan menghitung keseluruhan skor yang sudah diperoleh. Skor maksimum tiap aspek penilaian dari responden diperoleh dari jumlah butir penilaian dikali skor penilaian tertinggi. Rumus perhitungan yang digunakan adalah sebagai berikut:

$$
\text { Persentase Jawaban Responden }=\frac{\text { Jumlah Skor Yang Diperoleh }}{\text { Jumlah Skor Maksimum }} \times 100 \%
$$

Hasil dari skor penilaian yang telah diperoleh lalu dihitung rata-ratanya kemudian dikonversikan skor penilaiannya menjadi data kualitatif untuk menentukan kualitas dan tingkat kemanfaatan yang dihasilkan berdasarkan pendapat responden. Pengonversian skor dapat dilihat pada Tabel 2 berikut.

Tabel 2

Skala Kelayakan Produk (Buku Digital Muatan Pelajaran IPS)

\begin{tabular}{cl}
\hline Skor Persentase (\%) & Interpretasi \\
\hline $0 \%-25 \%$ & Sangat Kurang Baik \\
$26 \%-50 \%$ & Kurang Baik \\
$51 \%-75 \%$ & Baik \\
$76 \%-100 \%$ & Sangat Baik \\
\hline
\end{tabular}

\section{HASIL DAN PEMBAHASAN PENELITIAN}

Penelitian pengembangan ini menghasilkan sebuah produk berupa Buku Digital Muatan Pelajaran IPS berbasis Mobile Learning pada Materi Kerajaan-Kerajaan Hindu, Buddha, dan Islam di Indonesia Kelas IV SD. Penelitian pengembangan ini mengadopsi model pengembangan ADDIE yang meliputi lima tahapan yaitu, Analyze (analisis), Design (desain), Development (pengembangan), Implementation (implementasi), dan Evaluation (evaluasi). 
1224 Pengembangan Buku Digital Muatan Pelajaran IPS berbasis Mobile Learning pada Materi KerajaanKerajaan Hindu, Buddha, dan Islam di Indonesia - Juliandari Nur Fajri, Edwita, Yustia Suntari

DOI: https://doi.org/10.31004/edukatif.v4i1.1918

\section{Analysis (Analisis)}

Tahap pertama yang dilakukan oleh peneliti adalah melakukan analisis terhadap kelas IV SDN Utan Kayu Selatan 05. Analisis yang dilakukan meliputi analisis kebutuhan dan analisis kurikulum. Analisis kebutuhan dilakukan melalui wawancara dengan wali kelas IV dan peserta didik kelas IV SDN Utan Kayu Selatan 05. Melalui hasil analisis kebutuhan diperoleh bahwa minimnya ketersediaan bahan ajar dalam pembelajaran IPS, sehingga dibutuhkan bahan ajar dan sumber belajar yang dapat membantu peserta didik dalam memahami materi pembelajaran IPS, khususnya pada materi Kerajaan-Kerajaan Hindu, Buddha, dan Islam di Indonesia. Bahan ajar penunjang tersebut juga diharapkan dapat memperkaya wawasan dan ilmu pengetahuan peserta didik. Selanjutnya, analisis kurikulum meliputi analisis kurikulum 2013, analisis kompetensi dasar dan indikator pembelajaran, dan analisis materi pokok yaitu Kerajaan-Kerajaan Hindu, Buddha, dan Islam di Indonesia.

\section{Design (Perencanaan)}

Tahap kedua yang dilalui oleh peneliti adalah tahap perencanaan. Tahap-tahap perencanaan ini meliputi tahap perancangan materi, menentukan desain (penentuan ilustrasi dan warna, dan merancang kerangka buku), dan pembuatan sketsa (menggambar sketsa, penintaan pada sketsa, dan pewarnaan pada sketsa). Peneliti juga membuat rancangan instrumen penilaian yang akan digunakan untuk menilai kelayakan buku digital berbasis mobile learning yang dikembangkan. Buku digital yang dikembangkan terdiri atas sampul buku digital, kata pengantar, daftar isi, petunjuk penggunaan buku, kompetensi inti, dan kompetensi dasar, peta konsep, isi materi, glosarium, teka-teki silang (ayo mencoba), dan daftar pustaka.

\section{Development (Pengembangan)}

Tahap ketiga yang dilakukan peneliti yaitu pengembangan. Pada tahap pengembangan, peneliti banyak berdiskusi dengan illustrator terkait ilustrasi yang dibuat untuk buku digital. Sketsa ilustrasi yang telah dibuat kemudian dipindai (scanning), lalu dilakukan penintaan sketsa secara digital (inking) serta penyusunan layout buku secara keseluruhan.

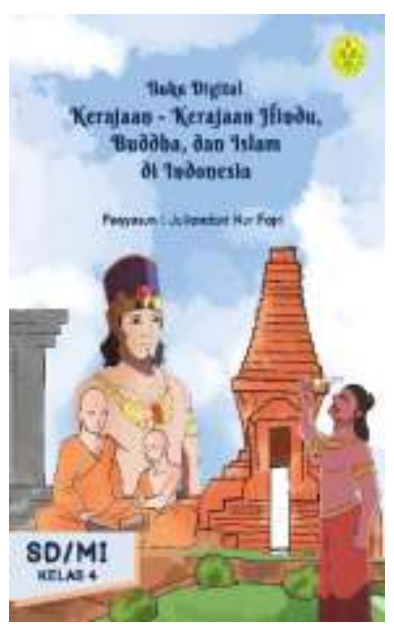

Sampul Buku Digital

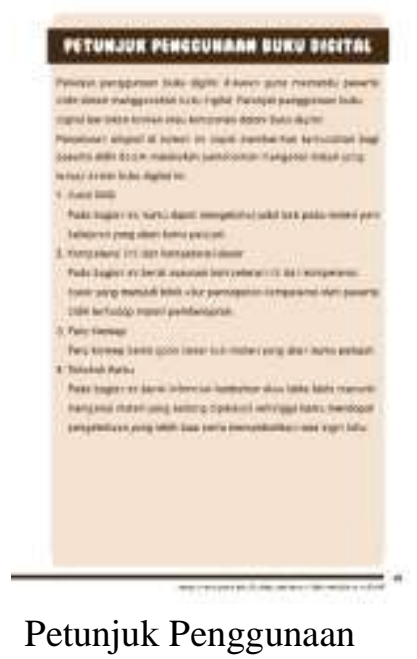

Petunjuk Penggunaan

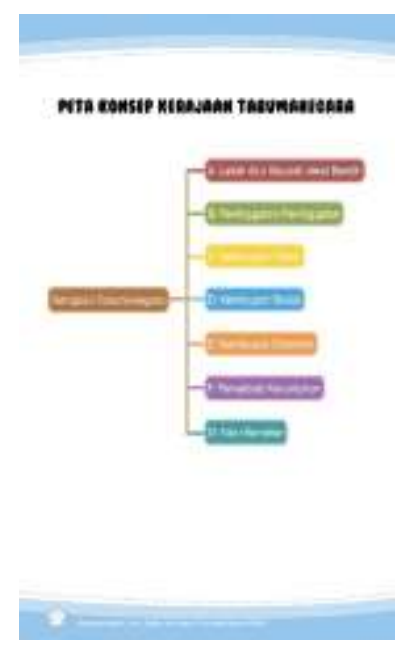

Peta Konsep 
1225 Pengembangan Buku Digital Muatan Pelajaran IPS berbasis Mobile Learning pada Materi KerajaanKerajaan Hindu, Buddha, dan Islam di Indonesia - Juliandari Nur Fajri, Edwita, Yustia Suntari DOI: https://doi.org/10.31004/edukatif.v4i1.1918

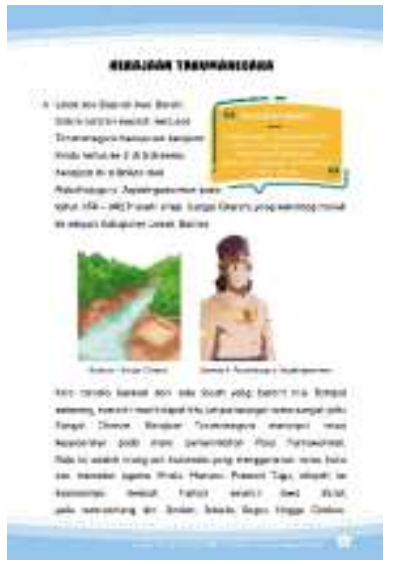

Isi Materi

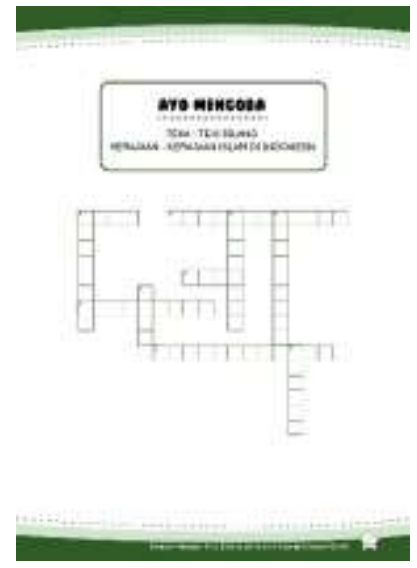

Teka-Teki Silang

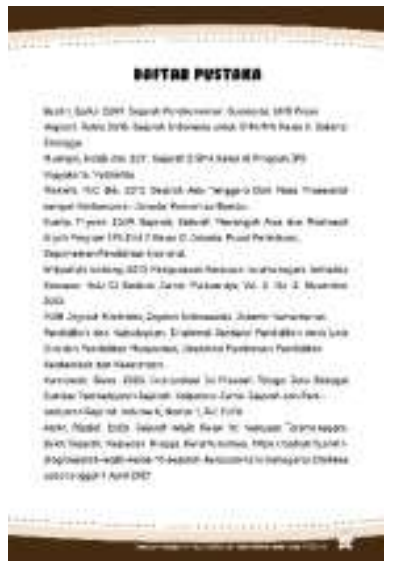

Daftar Pustaka

\section{Gambar 2. Hasil Pengembangan Buku Digital Muatan IPS Berbasis Mobile Learning}

(Sumber: Dokumentasi Pribadi)

\section{Implementation (Implementasi)}

Tahap selanjutnya adalah tahap implementasi. Pada tahap ini, peneliti akan melakukan expert review (uji ahli) yang melibatkan tiga orang ahli, yaitu ahli materi, ahli media, dan ahli bahasa. Dalam proses expert review, peneliti memberikan produk buku digital yang sudah dikembangkan untuk ditinjau serta memberikan lembar instrumen penilaian kelayakan produk untuk diisi oleh para ahli. Setelah produk yang dikembangkan oleh peneliti sudah mencapai kata layak dan valid dari ketiga ahli, maka produk tersebut akan diujicobakan kepada responden yang telah ditentukan oleh peneliti.

\section{Evaluation (Evaluasi)}

Tahap selanjutnya adalah tahap evaluasi. Tahap ini merupakan tahap akhir dari seluruh rangkaian tahap. Pada tahapan ini peneliti melakukan evaluasi formatif yaitu expert review (uji ahli) dan uji coba kepada responden peserta didik kelas IV SDN Utan Kayu Selatan 05 yang melalui tiga tahap yaitu one to one, small group, dan field test. Uji coba one to one dilakukan dengan 3 orang peserta didik, uji coba small group dilakukan dengan 6 orang peserta didik, dan field test dilakukan dengan 30 orang peserta didik. Setelah uji coba dengan menggunakan buku digital tersebut, peserta didik mengisi angket melalui Google Form untuk memberikan respon terhadap produk buku digital.

\section{Tabel 3}

Hasil Rekapitulasi Expert Review Keseluruhan Terhadap Buku Digital

\begin{tabular}{lcccc}
\hline Responden & Jumlah Butir & $\begin{array}{c}\text { Skor } \\
\text { Maksimum }\end{array}$ & $\begin{array}{c}\text { Skor } \\
\text { Perolehan }\end{array}$ & $\begin{array}{c}\text { Rerata Persentase } \\
\text { Penilaian }\end{array}$ \\
\hline Ahli Materi & 15 & 60 & 54 & $90 \%$ \\
Ahli Media & 23 & 92 & 92 & $100 \%$ \\
Ahli Bahasa & 10 & 40 & 40 & $100 \%$ \\
\hline Rerata Keseluruhan & & & $\mathbf{9 6 , 6 7 \%}$ \\
\hline
\end{tabular}

Berdasarkan Tabel 3, buku digital yang dikembangkan memperoleh penilaian dari uji ahli persentase sebesar 90\% dengan kategori sangat baik, untuk uji ahli media diperoleh persentase sebesar 100\% dengan kategori sangat baik, dan selanjutnya untuk uji ahli bahasa diperoleh persentase sebesar $100 \%$ dengan kategori sangat baik. Hasil uji ahli secara keseluruhan memperoleh rata-rata skor persentase sebesar 96,67\%, sehingga produk buku digital dapat masuk ke dalam kriteria sangat baik untuk digunakan peserta didik dalam pembelajaran, khususnya pembelajaran IPS. 
1226 Pengembangan Buku Digital Muatan Pelajaran IPS berbasis Mobile Learning pada Materi KerajaanKerajaan Hindu, Buddha, dan Islam di Indonesia - Juliandari Nur Fajri, Edwita, Yustia Suntari DOI: https://doi.org/10.31004/edukatif.v4i1.1918

Tabel 4

Hasil Rekapitulasi Uji Coba Peserta Didik Kelas IV SD Terhadap Buku Digital

\begin{tabular}{lcccc}
\hline \multicolumn{1}{c}{ Tahapan } & $\begin{array}{c}\text { Jumlah } \\
\text { Responden }\end{array}$ & $\begin{array}{c}\text { Skor } \\
\text { Maksimum }\end{array}$ & $\begin{array}{c}\text { Skor } \\
\text { Perolehan }\end{array}$ & $\begin{array}{c}\text { Rerata Persentase } \\
\text { Penilaian }\end{array}$ \\
\hline One to One & 3 & 120 & 109 & $90,8 \%$ \\
Small Group & 5 & 200 & 189 & $94,5 \%$ \\
Field Test & 30 & 1.200 & 1.091 & $90,91 \%$ \\
\hline
\end{tabular}

Tabel 4 menunjukkan bahwa pada tahap uji coba one to one peserta didik diperoleh hasil persentase sebesar 90,8\%. Selanjutnya, pada tahap uji coba small group diperoleh hasil persentase sebesar 94,5\%. Tahap terakhir yaitu uji lapangan atau field test diperoleh hasil persentase sebesar 90,91\%. Berdasarkan hasil uji coba yang telah melewati tiga tahap di atas, produk buku digital tidak mengalami revisi atau perbaikan. Hal ini disebabkan oleh produk buku digital yang masuk ke dalam penilaian dengan kriteria sangat baik.

\section{Pembahasan}

Penelitian yang dilakukan oleh peneliti berlangsung selama pandemi COVID-19, sehingga penelitian dilakukan secara daring. Peneliti memanfaatkan aplikasi Google Meeting untuk melakukan penelitian terhadap buku digital serta menggunakan Google Form sebagai media kuesioner yang nantinya diisi oleh peserta didik. Peserta didik diharapkan untuk mengisi kuesioner yang telah disediakan sebagai respon mereka terhadap buku digital yang diujicobakan. Pada saat peneliti mengadakan pertemuan online dengan responden peserta didik kelas IV SD, peserta didik terlihat antusias saat ditampilkan buku digital yang dikembangkan peneliti. Peserta didik tampak tertarik dengan sampul buku digital yang penuh dengan ilustrasi dan warna-warna ceria. Jenis huruf yang dipilih peneliti juga merupakan jenis huruf yang sederhana, menarik, dan mudah dibaca.

Pada saat peserta didik membaca isi materi buku digital, mereka juga antusias dan tertarik dengan ilustrasi yang disajikan karena ilustrasinya menarik dan selaras dengan materi yang dipelajari. Terlebih lagi saat peneliti menampilkan video yang berisi materi yang sedang dipelajari. Hal ini menyebabkan peserta didik semakin tertarik dan fokus dengan materi tersebut.

Peserta didik juga merasa diberi kemudahan dalam mengakses buku digital masing-masing karena hanya perlu satu kali mengunduh file buku digital yang didistribusikan oleh peneliti melalui aplikasi WhatsApp dan tidak membutuhkan akses internet berulang kali untuk mengaksesnya. Selain itu, peserta didik hanya membutuhkan memori penyimpanan perangkat lunak sebesar 7-10Mb untuk menyimpan buku digital. Peserta didik juga hanya memerlukan software e-book readers untuk membuka file buku digital dengan format .pdf. File buku digital dengan format .pdf memiliki nilai fleksibilitas, praktis, dan murah. Penelitian lain juga mendapat hasil bahwa e-book berbasis flipbook dinilai sangat layak dikarenakan respon peserta didik sangat memahami ketika menggunakan e-book tersebut (Meidita \& Susilowibowo, 2021). Selain itu terdapat penelitian lain yang menghasilkan buku digital yang mudah digunakan, mudah diakses, mudah dipahami baik dari segi materi ataupun bahasa, serta memiliki tampilan menarik, sehingga mendapatkan penilaian yang valid dari responden (Tambunan \& Sundari, 2020). Berdasarkan penelitian-penelitian terdahulu, maka dapat dikatakan bahwa penggunaan buku digital atau e-book dalam pembelajaran dapat memberikan pemahaman lebih terhadap materi yang diajarkan. Hal ini disebabkan karena buku digital memiliki nilai fleksibilitas, mudah dipahami, dan memiliki tampilan menarik. Penelitian-penelitian terdahulu tersebut juga menghasilkan temuan produk yang dinilai valid dari responden dan hal ini sejalan dengan hasil penelitian yang telah dijabarkan sebelumnya.

Penelitian ini tentu saja masih memiliki banyak keterbatasan. Pengembangan buku digital khususnya pada jenjang sekolah dasar masih belum banyak diteliti, sehingga peneliti menemui kesulitan saat mencari referensi penelitian terdahulu. Selain itu, pandemi menyebabkan adanya restrukturisasi kelas di sekolah populasi penelitian, sehingga penelitian hanya mampu dilaksanakan pada satu kelas di kelas IV SDN Utan Kayu Selatan 05. 
1227 Pengembangan Buku Digital Muatan Pelajaran IPS berbasis Mobile Learning pada Materi KerajaanKerajaan Hindu, Buddha, dan Islam di Indonesia - Juliandari Nur Fajri, Edwita, Yustia Suntari DOI: https://doi.org/10.31004/edukatif.v4i1.1918

Penelitian dan pengembangan mengenai buku digital ini dapat menjadi sebuah temuan yang dapat berpengaruh terhadap perkembangan keilmuan khususnya perkembangan bahan ajar non teks pelajaran berupa buku suplemen. Hal ini disebabkan pengembangan buku suplemen yang dikembangkan oleh peneliti ini memiliki output digital dalam format .pdf, sehingga dapat mendekatkan peserta didik dengan penggunaan teknologi informasi dan komunikasi dalam pembelajaran.

\section{KESIMPULAN}

Berdasarkan penelitian dan pembahasan yang telah diuraikan sebelumnya, maka dapat ditarik kesimpulan bahwa 1) Produk yang dihasilkan berupa buku digital muatan pelajaran IPS berbasis mobile learning pada materi Kerajaan-Kerajaan Hindu, Buddha, dan Islam di Indonesia; 2) Pengembangan produk buku digital mengacu pada model pengembangan ADDIE yang meliputi lima tahapan, yaitu Analyze (analisis), Design (desain), Development (pengembangan), Implementation (implementasi), dan Evaluation (evaluasi). 3) Buku digital muatan pelajaran IPS berbasis mobile learning pada materi Kerajaan-Kerajaan Hindu, Buddha, dan Islam di Indonesia merupakan produk yang valid dan layak untuk digunakan sebagai buku suplemen pada pembelajaran Ilmu Pengetahuan Sosial (IPS) di kelas IV sekolah dasar berdasarkan respon yang diperoleh dari ahli materi, ahli media, ahli bahasa, dan para peserta didik sebagai responden.

\section{DAFTAR PUSTAKA}

Abdillah, A., Degeng, I. N., \& Husna, A. (2020). Pengembangan Buku Suplemen dengan Teknologi 3D Augmented Reality sebagai Bahan Belajar Tematik untuk Siswa Kelas 4 SD. JINOTEP (Jurnal Inovasi Dan Teknologi Pembelajaran): Kajian Dan Riset Dalam Teknologi Pembelajaran, 6(2), 112. https://doi.org/10.17977/um031v6i22020p111

Branch, R. M. (2009). Approach, Instructional Design: The ADDIE. In Department of Educational Psychology and Instructional Technology University of Georgia. London: Springer Science+Bussiness Media. Tersedia [Online] https://www.pdfdrive.com/instructional-design-the-addie-approach-e25690406.html

Cholily, Y. M., Putri, W. T., \& Kusgiarohmah, P. A. (2019). Pembelajaran di Era Revolusi Industri 4.0. Seminar Nasional Penelitian Pendidikan Matematika (SNP2M) 2019 UMT, 1. http://jurnal.umt.ac.id/index.php/cpu/article/view/1674/1068

Chyung, S. Y. Y., Roberts, K., Swanson, I., \& Hankinson, A. (2017). Evidence-Based Survey Design: The Use of a Midpoint on the Likert Scale. Performance Improvement, 56(10), 5. https://doi.org/10.1002/pfi.21727

Danuri, \& Maisaroh, S. (2019). Metodologi Penelitian Pendidikan. Yogyakarta: Samudra Biru.

Febrianti, F. (2021). Pengembangan Digital Book Berbasis Flip PDF Professional untuk Meningkatkan Kemampuan Literasi Sains Siswa. 4(2), 113-114.

http://jurnal.ugj.ac.id/index.php/Caruban/article/view/5354.

Inah, Ety Nur. (2013). Peranan Komunikasi Dalam Pendidikan. Jurnal Al-Ta'dib, 6(1), 177.

Karim, A. (2015). Pembelajaran Ilmu Pengetahuan Sosial. Kudus: STAIN Kudus. http://eprints.stainkudus.ac.id/2130/1/BUKU Pembelajaran IPS.pdf.

Lidia Simanihuruk dkk. (2019). E-Learning: Implementasi, Strategi, dan Inovasinya. Medan: Yayasan Kita Menulis.

Marselina, V., \& Muhtadi, A. (2019). Pengembangan Buku Digital Interaktif Matematika pada Materi Geometri. Jurnal Inovasi Teknologi Pendidikan, 6(2), 206.

Masnur Muslich. (2010). Text Book Writing. Yogyakarta: Ar-Ruzz Media.

Meidita, A. C., \& Susilowibowo, J. (2021). Pengembangan Bahan Ajar E-Book Berbasis Flipbook sebagai 
1228 Pengembangan Buku Digital Muatan Pelajaran IPS berbasis Mobile Learning pada Materi KerajaanKerajaan Hindu, Buddha, dan Islam di Indonesia - Juliandari Nur Fajri, Edwita, Yustia Suntari DOI: https://doi.org/10.31004/edukatif.v4i1.1918

Pendukung Pembelajaran Administrasi Pajak dengan Kompetensi Dasar PPh Pasal 21. Edukatif: Jurnal Ilmu Pendidikan, 3(5), 2229-2230. https://doi.org/10.31004/edukatif.v3i5.784

Permendikbud. (2016). Peraturan Menteri Pendidikan Dan Kebudayaan Nomor 8 Tahun 2016 Tentang Buku Yang Digunakan Oleh Satuan Pendidikan.

Purwo, A., Utomo, Y., Isnarto., Afriandi, A., Pramono, D., Saputro, I. H., (2021). Optimalisasi Model Pelatihan Terpadu dalam Penyusunan Ebook, $1(1), 11$.

http://jurnalilmiah.org/journal/index.php/ji/article/view/7

Samsinar, S. (2020). Mobile Learning: Inovasi Pembelajaran di Masa Pandemi COVID-19. Al-Gurfah: Journal of Primary Education, 1(1), 44.

Saputro, B. (2017). Manajemen Penelitian Pengembangan (Research \& Development) bagi Penyusun Tesis dan Disertasi. Yogyakarta: Aswaja Pressindo.

Sugiyono. (2013). Metode Penelitian Kuantitatif, Kualitatif, dan R\&D. Bandung: Alfabeta.

Syahrum, \& Salim. (2014). Metodologi Penelitian Kuantitatif. Bandung: Citapustaka Media.

Tambunan, L. R., \& Sundari, E. (2020). Pengembangan Buku Digital Pada Materi Persamaan Garis Singgung Lingkaran. AKSIOMA: Jurnal Program Studi Pendidikan Matematika, 9(4), 1190. https://doi.org/10.24127/ajpm.v9i4.3084

Yayuk, E., \& -, K. (2017). Pengembangan Digibook Dalam Pembelajaran Tematik Tema Daerah Tempat Tinggalku Untuk Sekolah Dasar. JMIE (Journal of Madrasah Ibtidaiyah Education), 1(2), 155. https://doi.org/10.32934/jmie.v1i2.36 